\title{
RETORIKA DAKWAH DR. ZAKIR NAIK DALAM MENDA'WAHKAN ISLAM KEPADA KAUM NASHRANI
}

\author{
DOI: https://doi.org/10.38214/jurnaldawahstidnatsir.v4i01.91 \\ SAEFUL ROKHMAN \\ saeful@stidnatsir.ac.id \\ STID Mohammad Natsir - Indonesia \\ MUSLIMAH \\ muslimah@gmail.com \\ STID Mohammad Natsir - Indonesia
}

\begin{abstract}
ABSTRAK
Tujuan penelian ini untuk mengungkap retorika da'wah Dr. Zakir naik dalam menda'wahkan Islam kepada kaum Nashrani. Metode penelitian menggunakan kualitatif. Hasil dalam penelitian ini berdasarkan data-data yang bisa penulis dapatkan selama penelitian berlangsung kemudian penulis analisa berdasarkan teori Aristoteles, maka penulis dapat menyimpulkan sebagai berikut: Secara Ethos (sikap/kredibilitas komunikator), beliau menampakkan sikap bijak dalam menjawab semua pertanyaan dari komunikan. 2. Phatos (respon kumunikan). 3. Logos (isi pesan yang di sampaikan secara logis), isi pesan komunikasi yang banyak disampaikan oleh Dr. Zakir Naik ialah isi pesan yang disampaikan secara logis dan ilmiah, sehingga sangat mudah untuk mendapatkan respon yang positif dari setiap komunikan. Sebagaimana dibuktikan pada sebuah video yang di unggah pada Youtube.co.Lampu Islam pada tanggal 3 April 2017 di UMY (Universitas Muhammadiyah Yogyakarta) dengan dialog bertema wanita Kristen akhirnya mengakui kebenara Islam. Terbukti bahwa Dr. Zakir Naik beretorika didalam dakwahnya menggunakan teori retorika Aristoteles yaitu Ethos, Pathos, dan Logos. Dapat kita lihat Dr. Zakir Naik sanggup menunjukkan kepada khalayak bahwa dia memiliki pengetahuan yang luas dengan memberikan sebuah contoh dan analogi yang mudah dipahami, sehingga memiliki kepribadian yang terpercaya, dan status yang terhormat dihadapan khalayak. Selain itu Dr. Zakir Naik mampu menyentuh hati khalayak, emosi, harapan, kebencian dan kasih sayang peserta diskusi dengan argumen yang Dr. Zakir Naik sampaikan bahwa agama Islam adalah agama kedamaian. Kemudian Dr. Zakir Naik pun meyakinkan kahalayak dengan mengajukan bukti atau yang kelihatan sebagai bukti.
\end{abstract}

Kata kunci : retorika da'wah, Zakir Naik, Nashrani

\section{PENDAHULUAN}

Dalam proses dakwah tentunya sangat diperlukan seni beretorika. Karena salah satu keberhasilan dakwah dapat dilihat dari beberapa faktor penyebab di antaranya ialah materi dakwah yang disampaikan, kredibilitas seorang da'i, akhlak 
da'i, waktu yang tepat dalam menyampaikan, dan sarana yang digunakan dalam menyampaikan pesan-pesan dakwah, serta yang paling utama ialah ilmu retorika. Dimana, tatkala seorang da'i menyampaikan dakwahnya kepada mad'u, selain berbekal ilmu dan materi dakwah, ia juga harus mampu membahasakan dan mentransfer pengetahuan itu kepada mad'unya.

Retorika merupakan kemampuan dan kemahiran berbahasa yang dapat menciptakan kesan dalam hati pendengar terhadap apa yang disampaikan. Sebab dengan kepandaian penggunaan bahasa yang baik, maka pesan yang disampaikan cepat diterima oleh pendengar. begitu juga dengan retorika dakwah, semakin menarik suatu gaya bicara seseorang, semakin cepat pula pesan itu akan tersampaikan, sehingga akan menimbulkan kesan yang menarik, dan inspiratif bagi pendengarnya.

Dari kacamata komunikasi tampak bahwa retorika merupakan proses penyampaian pesan dari seorang pembicara kepada orang banyak, baik itu secara langsung (face to face) ataupun tidak langsung (mediated) baik lisan maupun tulisan.

Retorika juga berperan penting untuk seorang aktivis dakwah. Banyak da’i atau pendakwah yang tidak sampai pesannya kepada khalayak karena da'i tersebut tidak mampu menuangkan ke dalam bahasa yang baik, sehingga dakwah yang disajikan menoton, dan tidak menarik.

Seringkali retorika diisamakan dengan public speaking, yaitu suatu bentuk komunikasi lisan yang disampaikan kelompok orang banyak. Tetapi sebenarnya retorika itu bukan sekedar berbicara dihadapan umum, melainkan suatu gabungan antara seni berbicara dan pengetahuan atau masalah tertentu untuk meyakinkan pihak orang banyak melalui pendekatan persuasive. ${ }^{1}$

Oleh karena itu, retorika digunakan sebagai ilmu untuk memandu dan membimbing seorang da'i agar dapat merancang dan menampilkan kata dengan baik memiliki relevansi yang tinggi dan peran yang besar saat berdakwah.

Dari pengertian di atas, dapat disimpulkan bahwa retorika dakwah adalah kepandaian menyampaikan pesan secara lisan guna terwujudnya situasi dan kondisi yang Islami. Dakwah menginginkan terjadinya perubahan kearah kehidupan yang lebih baik dan Islami. Sebagaimana Allah Subbanabu wa Ta'ala berfirman:

Artinya: "Serulah (manusia) kepada jalan Tuban-mu dengan bikmab [845] dan pelajaran yang baik dan bantablah mereka dengan cara yang baik. Sesunggubnya Tubanmu dialah yang lebih mengetahui tentang siapa yang tersesat dari jalan-Nya dan dialah yang lebih mengetabui orang-orang yang mendapat petunjuk.”(Q.S. An-Nahl: 125)

Karya

${ }^{1}$ Jalaludin Rakhmat, Retorika Modern: Pendekatan Praktis, Bandung: PT Remaja Rosda 
Seiring perkembangan zaman, dakwah melalui sosial media sangatlah cepat diterima. Hampir semua kalangan masyarakat saat ini mempunyai akses internet dan memilih program yang mereka senangi sebagai hiburan, wawasan ataupun tambahan ilmu pengetahuan baik agama ataupun umum.

Dakwah dan teknologi adalah suatu yang tidak dapat dipisahkan. Hal ini jika kita berpijak pada konsep dakwah kontemporer yang mudah diterima oleh kalangan masa kini. Teknologi bukan suatu yang dilarang, meskipun di masa Rasulullah belum ditemukan adanya teknologi seperti yang berkembang pada saat ini.

Perkembangan dakwah perlu memperhatikan perkembangan teknologi. Walaupun tidak semua teknologi informasi yang berkembangan saat ini bersifat positif, ada kelebihan dan kekurangannya bagi kehidupan umat manusia, dengan adanya teknologi informasi dapat dimanfaatkan sebagai media dakwah Islam.

Salah satu media sosial yang paling populer adalah youtube. Youtube merupakan salah satu media yang paling sering di akses oleh pengguna internet, menurut Vice President of Enginering Youtube Cristos Goodrow dalam kompas Tekno dari thenextweb.com, durasi orang menonton video di platform tersebut telah meningkat drastis, totalnya mencapai satu miliar jam per hari dan memiliki lebih dari satu miliar pengguna, hampir sepertiga dari semua pengguna internet mengakses youtube setiap harinya dan menghasilkan miliar kali penanyangan.

Dengan adanya pernyataan di atas sudah menjadi bukti yang jelas bahwa youtube telah memiliki pengaruh yang besar sebagai media dakwah yang bebas dan bisa ditonton oleh semua orang. ${ }^{2}$ Dan salah satu channel youtube yang besar pengaruhnya ialah "Lampu Islam".

Lampu Islam adalah sebuah channel youtube yang secara kontinyu mengupload video-video Islam hampir setiap harinya, selain itu juga ia adalah channel dakwah yang banyak dilihat orang. channel Lampu Islam saat ini sudah terverifikasi oleh youtube, dan video-videonya yang di posting telah dilihat lebih dari puluhan juta bahkan hampir seratus juta orang. ${ }^{3}$ Dan salah satu video dakwah yang sering ditayangkan ialah video dakwah Dr. Zakir Naik.

Untuk itu penulis mengangkat seorang tokoh yang tidak asing lagi namanya di tengah-tengah masyarakat, Yakni tokoh dakwah atau pakar kristolog yang sangat terkenal akan argumentasinya dalam meyakinkan kebenaran ajaran Islam kepada kaum Nashrani. ia adalah seorang dokter kelahiran 1965 dari

\footnotetext{
2 www.dictio.id 5 Januari 2019

3 https://m.kitabisa.com 5 Januari 2019
} 
Mumbai (India). Nama lengkapnya "Zakir Abdul Karim Naik" atau biasa disebut dengan Dr. Zakir Naik. ${ }^{4}$

Sosoknya begitu melejit dan terkenal di Indonesia. Video-videonya pun sudah banyak diterjemahkan ke dalam bahasa Indonesia dan diunggah ke Youtube secara besar-besaran, hal ini sudah berlangsung beberapa tahun lamanya. Dr. Zakir Naik tampil memberi semangat baru. Dengan kemampuan public speaking yang memukau, dokter medis ini berhasil menjadi pendakwah internasional. Dia mendapatkan pujian dari seluruh dunia untuk presentasi dakwah yang menarik dengan pendekatan logika dan sains, untuk menghilangkan kesalahpahaman tentang ajaran Islam ke seluruh muka bumi.

Dr. Zakir Naik berhasil meraih kesuksesan lewat kata-kata. Dr. Zakir Naik, yang mampu menghipnotis puluhan ribu para pendengarnya dengan bahasanya yang tidak hanya berdasarkan pada ajaran Islam saja, melainkan mampu mengkombinasikan dengan ajaran agama lain yang kemudian dibungkus dengan retorika atau argumen yang menarik dan masuk akal, sehingga argumen yang dipakai oleh Dr. Zakir Naik mudah untuk dipahami orang lain.

Dr. Zakir Naik juga terkenal sebagai ulama yang ahli dalam ilmu perbandingan agama. Analisisnya yang kritis dan jawabannya yang spontan mampu meyakinkan setiap pertanyaan yang diajukan saat terjadi dialog.

Kemampuan yang dimilikinya berupa hafalan yang sangat kuat tidak hanya mampu menghafalkan Al-Qur'an dan Shahih Bukhari Muslim, akan tetapi beliau juga telah menguasai kitab Bibel, Weda, Tripitaka, Bhagavad gita, bahkan telah menggerakkan hati ribuan penganut Hindu di India dan menjadikan muallaf.

Tidak hanya di India, kaum Nashrani yang ada di negara seperti Amerika Serikat, Kanada, Inggris, Italia, Prancis, Arab Saudi, Kuwait, Qatar, Bahrain, Oman, Mesir, Australia, Selandia Baru, Afrika Selatan, Botswana, Malaysia, Indonesia dan masih banyak negara lainnya yang telah di muallafkan. ${ }^{5}$ Cara berdakwah Dr. Zakir Naik yang santun dan bijak, disertai keilmuannya yang tinggi, beliau juga mengerti etika berdebat yang harus dilakukan ketika berhadapan dengan publik luas.

Dahulunya beliau adalah seorang Dokter profesional, akan tetapi setelah beliau menyadari bahwa da'i adalah profesi yang lebih baik dan jauh lebih unggul daripada Dokter, maka beliau merubah profesinya dari Dokter tubuh menjadi Dokter ruhani. Pada umur 36 tahun, Dr. Zakir Naik telah menerangkan agama Islam terutama kepada kaum Nashrani, yakni meluruskan pendapat yang keliru mengenai agama Islam dengan berdasarkan Al-Qur'an dan As-Sunnah,

\footnotetext{
4 Zakir Naik, dkk, Mereka Bertanya Islam Menjawab, Solo: Aqwam, Cet. IX, hal. 325

${ }^{5}$ Hajir Tajiri, Etika dan Estetika Dakwah, hal. 11
} 
menguatkannya dengan ilmu logika juga ilmu lainnya yang semuanya berpengaruh.

Beliau banyak mengutip dalam Al-Qur'an dan juga dari kitab-kitab agama lain. Dr. Zakir Naik terkenal dengan analisa detailnya dan dengan jawaban yang meyakinkan dari setiap pertanyaan yang diajukan. Selain itu juga, Dr. Zakir Naik sering muncul secara berkala di banyak stasiun TV internasional dan di Channel TV Satelit lebih dari 100 Negara di Dunia. Beliau juga sering di undang dalam wawancara Radio. Dan beliau juga telah menulis beberapa buku tentang: Mengenal Islam dan Agama lainnya, Mereka Bertanya Islam Menjawab, Debat Islam dan Non-Islam, dan Miracles of Al-Qur'an dan As-Sunnah.

Dr. Zakir Naik terkenal sebagai ahli perbandingan agama yang dianggap berhasil membongkar "kesalahan" agama lain. Dalam berbagai ceramahnya, dia tidak hanya mengutip secara panjang lebar ayat-ayat dari Al-Qur'an dan Hadits, tapi juga dari kitab-kitab agama lain.

Perbandingan agama yang kerap dipakai oleh Dr. Zakir Naik tujuannya bukan semata-mata untuk membanding-bandingkan Islam dengan agama-agama lain atau antara umat Islam dan umat-umat lain. Sebab, orang muslim juga diperintahkan untuk menghormati keyakinan-keyakinan lain. Namun, jika ada yang bertanya tentang keraguan akan kebenaran akan agama Islam, maka orangorang Islam punya kewajiban untuk menyampaikannya secara terbuka, jujur, dan bahkan diperbolehkannya berdebat dengan umat lain menurut etika perdebatan Islam. ${ }^{6}$

Melihat kegiatan misionaris yang dilakukan oleh kaum Nashrani yang terlalu agresif, Dr. Zakir Naik mempunyai misi khusus dalam mendakwahi mereka. Menurutnya kegiatan misionaris yang telah melampaui batas kewajaran tidak boleh dibiarkan, dan harus dibuktikan dengan dakwah Bil-Lisan, yakni media dakwah menggunakan ceramah dengan cara menjawab secara bijak setiap pertanyaan yang diajukan oleh kaum Nashrani akan keraguan mereka tentang ajaran umat Islam. ${ }^{7}$

Dan sampai saat ini, komunikasi dakwah yang kerap diterapkan oleh Dr. Zakir Naik dalam meyakinkan agama Islam kepada kaum Nashrani ialah dengan berdialog, Karena dialog adalah metode yang paling efektif untuk menjembatani lintas peradaban dan kebudayaan. Melalui sarana ini, informasi dan data yang benar dapat disampaikan kepada oranglain. Melalui dialog pula, argumentasi dan hujjah dapat dikemukakan sehingga syubhat dapat ditepis dan masyarakat dapat berinteraksi dengan kebenaran. ${ }^{8}$

\footnotetext{
${ }^{6}$ Zakir Naik, dkk, Mereka Bertanya Islam Menjawab, hal. 323

7 Wahyu Ilahi, Komunikasi Dakwah, hal. 20

8 Zakir Naik, dkk, Mereka Bertanya Islam Menjawab, hal. xi
} 
Berangkat dari permasalahan di atas, maka penulis berkeinginan untuk mengadakan penelitian skripsi berjudul "Retorika Dakwah Dr. Zakir Naik dalam Meyakinkan Kebenaran Ajaran Islam kepada Kaum Nashrani (Analisis Terhadap Dialog Dr. Zakir Naik di Youtube.co.Lampu Islam)". Oleh karena itu penulis ingin mendalami dan menggali informasi tentang retorika dakwah yang disampaikan oleh Dr. Zakir Naik, ketika berdialog dengan kaum Nashrani.

Berdasarkan pemikiran dan permasalahan di atas, maka tujuan penelitian ini adalah untuk mengetahui "Retorika Dakwah Dr. Zakir Naik dalam Meyakinkan Kebenaran Ajaran Islam kepada Kaum Nashrani" (Analis Terhadap Dialog Dr. Zakir Naik di Youtube.co.Lampu Islam).

Dalam penelitian ini penulis menggunakan penelitian kualitatif, yaitu penelitian yang dilakukan dengan menggunakan kata-kata atau kalimat dari individu, buku atau sumber lain. ${ }^{9}$ Data yang dikumpulkan lebih mengambil bentuk kata-kata atau gambar daripada angka-angka. Penelitian kualitatif juga lebih ditujukan untuk mengungkapkan makna dari pandangan subjek yang diteliti untuk mendapatkan pemahaman tentang fenomena yang diteliti secara luas, menyeluruh, dan mendalam, bukan ditujukan untuk mencari generalisasi.

Pendekatan kualitatif adalah dengan memusatkan perhatian pada prinsipprinsip umum yang mendasari perwujudan sebuah makna dari gejala-gejala sosial di dalam masyarakat. ${ }^{10}$ Prosedur penelitian yang menghasilkan data deskriptif berupa kata-kata tertulis atau lisan dari orang-orang dan perilaku yang dapat diamati. ${ }^{11}$

Dalam penelitian kualitatif ini, peneliti menggunakan analisis isi (content analysis). Analisis isi (content analysis) adalah suatu teknik penelitian untuk membuat inferensi yang dapat direplikasi (ditiru) dan sahih datanya dengan memerhatikan konteksnya, ${ }^{12}$ penelitian yang bersifat pembahasan mendalam terhadap isi suatu informasi tertulis atau tercetak dalam media massa. Analisis isi merupakan salah satu metode utama dari ilmu komunikasi. Penelitian yang mempelajari isi media (surat kabar, radio, film, dan televisi) yang menggunakan analisis isi. Lewat analisis isi, pe neliti dapat mempelajari gambaran isi, karakteristik pesan, dan perkembangan dari suatu isi. ${ }^{13}$

\footnotetext{
${ }^{9}$ Nanang Martono, Metode Penelitian Kualitatif, Analisis isi dan Analisis data sekunder, Jakarta: Rajawali Pres, 2011, hal. 20

${ }_{10}$ M. Burhan Bunggin, Sosiologi Komunikasi, Teori, Pradigma, dan Diskursus, Teknologi Komunikasi di Masyarakat, hal. 306

${ }^{11}$ Nurul Zuriah, Metodologi Penelitian Sosial dan Pendidikan, Teori-Aplikasi, Jakarta: Aksara, 2009, Cet. III, hal. 92

${ }^{12}$ Eriyanto, Analisis Isi, Pengantar Metodologi untuk Penelitian Komunikasi dan Ilmu-ilmu Sosial lainnya, Jakarta: Kencana Prenada Media Group, 2011, Cet. I, hal. 15
}

${ }^{13}$ Ibid., hal. 11 
Teks (berita, iklan, selebaran, pidato, buku, film, dan semuanya) memberikan sumber berharga bagi peneliti dalam mempelajari masyarakat. Analisis isi membantu melakukan konseptualisasi dan kategori dari isi dokumen ini sehingga dapat dikategorikan dan dinalisis. ${ }^{14}$

Analisis isi merupakan metode penelitian yang digunakan untuk mengetahui simpulan dari sebuah teks. Atau dengan kata lain, analisis isi merupakan metode penelitian yang ingin mengungkap gagasan penulis yang termanifestasi maupun yang laten. Oleh karenanya, secara praktis metode ini dapat digunakan untuk berbagai macam tujuan, seperti; menjembatani isi dari komunikasi internasional, membandingkan media atau level dalam komunikasi, mendeteksi propaganda, menjelaskan kecenderungan dalam konten komunikasi.

Langkah awal yang penting dalam analisis isi ialah menentukan unit analisis. Krippendorff (2007: 97), mendefinisikan unit analisis sebagai apa yang diobservasi, dicatat dan dianggap sebagai data, memisahkan menurut batasbatasnya dan mengidentifikasi untuk analisis berikutnya. Unit analisis secara sederhana dapat digambarkan sebagai bagian apa dari isi yang kita teliti dan kita pakai untuk menyimpulkan isi dari suatu teks. Bagian dari isi ini dapat berupa kata, kalimat, foto, scene (potongan adegan), paragraf. Bagian-bagian ini harus terpisah dan dapat dibedakan dengan unit yang lain, dan menjadi dasar kita sebagai peneliti untuk melakukan pencatatan. Sebagai misal, peneliti membuat penelitian mengenai kandungan kekerasan dalam film kartun. Bagian apa dari kartun ini yang akan kita teliti untuk mengetahui besarnya kandungan kekerasan. Apakah yang dilihat adalah karakternya (tokoh), adegannya, cerita, dan penyelesaian masalah. Bagian "apa" dari kartun inilah yang kita sebut sebagai unit analisis. Penentuan unit analisis yang tepat akan menjamin bahwa temuan analisis isi akan dapat menjawab tujuan dari penelitian. ${ }^{15}$

\section{HASIL DAN DISKUSI}

Pada bagian ini, penulis akan melakukan analisis terhadap dialog Dr. Zakir Naik dalam channel youtube Lampu Islam dengan menggunakan metode content analysis (analisis isi) dari teori retorika Aristoteles. Adapun dalam teknisnya penulis akan menganalisis dialog Dr. Zakir Naik dalam channel youtube Lampu Islam, karena dalam pandangan Aristoteles penelitian tidak cukup menganalisis atas dasar isi pesan dialog semata, akan tetapi dialektika dan retorika yang bisa digunakan untuk menarik kesimpulan dari kedua sisi yang berlawanan secara netral.

\footnotetext{
14 Ibid., hal 12

15 Eriyanto, Analisis Isi, Pengantar Metodologi untuk Penelitian Ilmu Komunikasi dan Ilmu-ilmu Sosial lainnya, Jakarta: Kencana Prenada Media Group, 2011, Cet. I, hal. 60-61
} 
Content analysis (analisis isi) dari teori retorika Aristoteles disebutkan bahwa ada tiga cara untuk mempengaruhi manusia. Yaitu, ethos (sikap), pathos (respon) dan logos (isi). Inti dalam content analysis (analisis isi) dari teori retorika Aristoteles adalah menggabungkan ketiga dimensi tersebut dalam satu kesatuan analisis.

Dr. Zakir Naik secara tidak langsung menguraikan jawabnnya menggunakan teori Aristoteles yaitu Ethos, Pathos, dan Logos. Dr. Zakir Naik sanggup menunjukkan kepada khalayak bahwa dia memiliki pengetahuan yang luas dengan memberikan sebuah contoh dan analogi yang mudah dipahami, sehingga memiliki kepribadian yang terpercaya, dan status yang terhormat dihadapan khalayak. Selain itu Dr. Zakir Naik mampu menyentuh hati khalayak, emosi, harapan, kebencian dan kasih sayang peserta diskusi dengan argumen yang Dr. Zakir Naik sampaikan bahwa agama Islam adalah agama kedamaian. Kemudian Dr. Zakir Naik pun meyakinkan kahalayak dengan mengajukan bukti atau yang kelihatan sebagai bukti. Disini Dr. Zakir Naik mendekati khalayak lewat otaknya dengan mengajukan bukti berupa ayat dalam Al-Qur'an dan dari kitab agama lain.

Adapun tiga dimensi tersebut dalam analisis penulis terhadap retorika Dr. Zakir Naik pada video youtube dalam dialog yang bertemakan: Wanita Kristen akhirnya mengakui kebenaran Islam, Yang akan dianalisis sebagai berikut:

\section{Ethos}

Menjaga kredibilitas/sikap seorang komunikator ketika berdialog dengan memiliki wawasan yang luas dengan menguasai retorika. Pada sikap ini kita harus sanggup menunjukkan kepada khalayak bahwa kita memiliki pengetahuan yang luas, kepribadian yang terpercaya, dan status yang terhormat.

Setelah mendengarkan dan membaca teks pada video yang terdapat dalam youtube, penulis menyimpulkan bahwa sikap/kredibilitas yang Dr. Zakir Naik tampilkan pada video ini adalah pengetahuannya dalam seni beretorika. Yakni dimana beliau tidak pernah berargumen berdasarkan perasaan dan emosinya, melainkan selalu merujuk kepada buku-buku atau teks-teks yang sudah valid dan dijamin kebenarannya. Contohnya video dialog pada detik ke: 00:00:49-00:01:17, seorang wanita Kristen yang beranama Damanita dan berumur 35 tahun mengatakan bahwa dia belum siap untuk jadi Muslim, karena masih ada yang mengganjal dan masih kebingungan. Jadi ia ingin menanyakan kepada Dr. Zakir Naik, yakni tentang:

"bagaimana jika aku menjadi Muslim, dan aku bersembunyi dari keluarga, temantemanku, atau lingkunganku, apakah itu dibolehkan?”.

Dari pertanyaan ini, bisa dilihat sikap/kredibilitas Dr. Zakir Naik dalam menjawab suatu pertanyaan yang diajukan oleh wanita Nashrani. Yakni memberikan pengetahuan yang luas serta jawaban yang dapat dipercaya. Dengan 
tujuan agar sikap ini menjadikan status seorang Muslim tetap menjadi pribadi yang jujur dan terhormat.

sebelum menjawab pertanyaan Dr. Zakir Naik menyambut pertanyaan dengan senyuman dan mengatakan "saudari menanyakan pertanyaan yang sangat penting”. Dalam dialognya Dr. Zakir Naik sangat menghormati wanita tersebut dengan sangat menghargai tamu-tamu dari kaum Nashrani yang tidak diundang, dan berniat untuk mengajukan sebuah pertanyaan yang mengganjal tentang kebenaran ajaran Islam.

Jawaban Dr. Zakir Naik dapat dilihat dalam video dialog pada menit ke: 00:01:31-00:02:08, disini Dr. Zakir Naik mengulang perkataan dari wanita Nashrani tentang alasan dia sulit untuk masuk ke dalam ruangan untuk bertanya. Dr. Zakir Naik mengatakan:

"Sebelum dia bertanya, dia berkata babwa dia agak kesulitan untuk masuk ke dalam untuk mendengar pesan kedamaian (Islam). Aku ingin memberitahu para organizer untuk ceramah selanjutnya, tolong kau sebutkan, aku tabu banyak orang melakukan registrasi dan aku melihat begitu banyak pesan dari ratusan orang dimana mereka berkata tidak bisa masuk ke dalam. Setidaknya cantumkan dalam iklannya bahwa non-Muslim tidak perlu registrasi. Tolong! Jika kau tidak mengizinkan para non-Muslim untuk masuk, maka ini tidak adil. Allab akan meminta pertanggung jawaban kita di hari kiamat. Babkan jika semua Muslim harus di luar, tidak masalah. Seperti yang kusebutkan babwa non-Muslim adalah tamu kehormatan kita".

Disini tampak sikap Dr. Zakir Naik sangat menghormati kaum Nashrani bahwa kaum Nashrani adalah tamu kehormatan bagi umat Islam yang sangat membutuhkan dakwah Islam. Sebagaimana keraguan-keraguan yang ada pada diri kaum Nashrani tentang agamanya sendiri, maupun belum bisa percaya 100\% mempercayai agama yang haq yakni kebenaran ajaran Islam yang Allah turunkan di muka bumi ini sebagai rahmat, karena sedikit sekali dari umat Islam yang belum bisa meyakinkan kepada kaum Nashrani tentang agama Islam dengan cara berdialog kepada non-Muslim dengan memberikan sikap yang dapat dipercaya dan argumen yang meyakinkan bagi para pendengarnya (kaum Nashrani).

Setelah itu, Dr. Zakir Naik dengan sangat bijak menjawab pertanyaan yakni meyakinkan pada diri wanita Nashrani agar jangan takut untuk masuk Islam dan sebuah kewajiban untuk membagikan berita kedamaian ini kepada orangtua, saudara, dan kepada teman-teman. Karena kita adalah agen bagi kedamaian, dan jika tidak disampaikan pesan kedamaian itu, maka kelak di hari kiamat mereka akan bersaksi bahwa kita tidak pernah menyampaikan pesan kedamaian (Islam).

Setelah itu, Dr. Zakir Naik juga memberikan saran kepada wanita Nashrani tersebut, apabila belum berani untuk mengumumkan dan menyampaikannya sekarang, maka bisa menyembunyikannya untuk jangka waktu 
tertentu, dan itu tidak jadi masalah untuk kita yang ingin mengamalkan ajaran Islam dan tidak menjadi penghambat untuk kita menjalankan ajaran Islam.

Setelah mendengar jawaban dan sikap yang meyakinkan dari Dr. Zakir Naik yang jelas, lugas dan sangat bisa diterima oleh akal pemikiran, pada akhirnya wanita Nashrani inipun menyatakan dirinya siap untuk memeluk agama Islam. Berdasarkan hal tersebut Dr. Zakir Naik dapat Menjaga kredibilitas/sikapnya ketika berdialog dengan memiliki wawasan yang luas (menguasai retorika). Pada sikap ini beliau sanggup menunjukkan kepada khalayak bahwa dia memiliki pengetahuan yang luas, kepribadian yang terpercaya, dan status yang terhormat.

Setelah mendengarkan dan membaca teks pada video yang terdapat dalam youtube, penulis menyimpulkan bahwa sikap/kredibilitas yang Dr. Zakir Naik tampilkan pada video ini adalah pengetahuannya dalam seni beretorika. Yakni dimana beliau tidak pernah berargumen berdasarkan perasaan dan emosinya. Kemudian Dr. Zakir Naik sanggup menunjukkan kepada khalayak bahwa dia memiliki pengetahuan yang luas dengan memberikan sebuah contoh dan analogi yang mudah dipahami, sehingga memiliki kepribadian yang terpercaya, dan status yang terhormat dihadapan khalayak.

\section{Pathos}

Elemen selanjutnya adalah pathos, yakni faktor respon emosional pada komunikan/pendengar. dapat diartikan sebagai respon dari pendengar setelah mendengarkan pesan yang disampaikan oleh komunikator. Kita bisa mengetahui atau melihat orang seperti apa yang menjadi objek dari argumen ini. Respon atau emosi yang dimaksud adalah rasa marah, hasrat, serta keinginan sehingga dapat menimbulkan rasa ingin untuk melakukan suatu tindakan atau suatu perubahan.

Yang akan diteliti pada elemen pathos ini adalah bagian mana yang terdapat respon yang menyebabkan pendengar mengalami suatu perubahan ke arah positif. Pada dialog ini dapat dilihat sebagaimana berikut pemaparan dari video dialog pada menit ke: 00:05:28, Dr. Zakir Naik menanyakan secara langsung tentang: "Apakah engkau percaya Tuban itu satu?". Setelah mengatakan dan meyakinkan panjang lebar tentang agama Islam adalah agama damai, kemudian Dr. Zakir Naik mengajukan pertanyaan secara langsung kepada wanita Nashrani yakni tentang percaya atau tidaknya bahwa Tuhan itu satu.

Dan respon dari wanita Nashrani tersebut terdapat pada menit ke: 00:05:33, bahwa ia mengatakan: "Aku percaya". Kemudian Dr. Zakir Naik mengajukan pertanyaan lagi secara tegas yakni pada menit ke: 00:05:36-00:06:10, "Apa engkau percaya Yesus Kristus sebagai nabi Tuban atau Tuban?”, dan ditegaskan lagi, "Apa engkau percaya Yesus Kristus sebagai Tuban, atau engkau percaya dia nabi Tuban?".

Dan pada menit ke: 00:06:12, terdapat respon dengan raut muka yang sangat yakin wanita Nashrani mengatakan: "Sekarang aku percaya dia nabi Tuhan". 
Setelah mendengar jawaban itu, Dr. Zakir Naik langsung memberikan pertanyaan lagi pada menit ke: 00:06:21, "Sister, apakah engkau percaya bahwa Nabi Muhammad Shallallabu'alaibi wa Sallam adalab nabi Tuhan?” berhenti sejenak dan ia menjawab “ maaf sekali, tapi belum saatnya aku masib belajar tentang nabi Mubammad dan aku masih bingung" kemudian Dr. Zakir naik menjelaskan dan mengulangi pertanyaan yang tadi sebagai kata penekanan, "Apa engkau percaya Nabi Muhammad Shallallahu'alaibi wa Sallam sebagai nabi Tuban?". Setelah beberapa pertanyaan yang diajukan oleh Dr. Zakir Naik, dan dijawab dengan penuh rasa yakin bahwa ia mengatakan ya, percaya! akan tetapi ia belum siap untuk mengumumkannya di depan umum. Setelah menjawab dari beberapa pertanyaan yang diajukan oleh Dr. Zakir Naik, maka wanita Nashrani yang bernama Damanita dinyatakan masuk Islam, karena untuk menjadi Muslim, harus punya dua hal. yang pertama, percaya Tuhan itu satu dan yang kedua percaya bahwa Nabi Muhammad Shallallahu'alaibi wa Sallam adalah nabi.

Jadi, kesimpulan yang dapat diambil dari respon pada video ini, bahwa wanita Nashrani setelah mendengakan perkataan dan sikap dari Dr. Zakir Naik ketika menyampaikan dakwahnya telah dikatakan berhasil. Karena wanita Nashrani yang bernama Damanita telah mau mengakui kebenaran ajaran Islam meski masih secara sembunyi-sembunyi.

\section{Logos}

Elemen terakhir pada penelitian ini adalah logos, yakni isi pesan komunikasi. Mencakup imbauan berdasarkan argumen yang logis. Disini kita harus dapat meyakinkan pendengar dengan mengajukan bukti atau dalil-dalil yang dapat meyakinkan kebenaran ajaran Islam.

Untuk memberikan bukti pada suatu isi pesan yang disampaikan, maka sangat diperlukan membuat argumen yang masuk akal. Pertama-tama membahas argumen dengan adanya contoh, karena contoh memiliki sifat induksi, yang merupakan dasar dari penalaran logis. Bentuk argumen ini terdiri dari dua jenis: penyebutan fakta masa lampau aktual dan fakta yang ditemukan oleh pembicara.

Ketika tidak dapat menggunakan entimem (silogisme retorik) untuk membuat argumen, kita harus bisa mendemonstrasikan pembuktian kita dengan contoh, untuk dapat meyakinkan pendengar. jika kita dapat berargumen dengan entimem, contoh harus digunakan sebagai bukti tambahan lanjutan. Contoh tidak boleh mendahului entimem, karena akan memberi kesan induktif pada argumen, yang jarang sekali untuk pidato/suatu dialog. Jika contoh mengikuti entimem, contoh akan memberi efek seperti saksi yang memberikan bukti, dan saksi selalu bisa menarik kepercayaan. Contohnya dalam video dialog Dr. Zakir Naik pada menit ke: 00:06:41-00:09:03,

"Apakah engkau sudab melihat ceramabku tentang Nabi Mubammad Shallallabu'alaibi wa Sallam? ya. Dia dinubuatkan tidak hanya dalam satu kitab, 
dia dinubuatkan dalam kitab berbagai agama besar di dunia. Dia babkan dinubuatkan dalam Perjanjian Lama, dalam kitab Ulangan 18:18, di kitab Ulangan 18:19, di kitab Yesaya 29:12, di Kidung Agung 5:16. Dia babkan dinubuatkean di Perjanjian Baru di Bibel, di gospel Yobanes 14: 16, di gospel Yohanes 15:26, di gospel Yohanes 16: 7, di gospel Yohanes 16: 12-24, ini disebutkan babwa Yesus Kristus berkata, "Masib banyak yang masib harus kukatakan padamu, tapi kamu belum dapat menanggungnya sekarang,tetapi apabila dia datang, dia akan memimpin kamu ke dalam seluruh kebenaran; Dia tidak berkata dari diri sendiri, segala yang didengarnya yang akan dikatakan. Dia akan memuliakan aku." Disini nabi Yesus memberitahu kepada para pengikutnya, "Masih banyak yang masih yang harus kukatakan padamu, tapi kamu belum dapat menanggungnya sekarang, kamu belum bisa ngerti sekarang, tapi ketika Dia (roh kebenaran) itu datang." Ini membicarakan Nabi Mubammad Shallallabu'alaibi wa Sallam. "Dia akan memimpin kamu ke dalam kebenaran. Dia tidak berkata dari diri sendiri, segala yang didengarnya yang akan dikatakan. Dia akan memuliakan aku." Dan kita tahu bahwa Nabi Mubammad Shallallabu'alaibi wa Sallam mendapat wabyu dari Allah Subhanabu wa Ta'ala, dan apapun yang diwabyukan padanya, dia mengatakannya secara harfiah dan mengumumkannya ke dunia. Jadi dalam Bibel, ada banyak nubuat tentang kedatangan nabi penutup dan terakbir termasuk. oleh Nabi Yesus. Nabi Yesus membicarakan tentang nabi lain yang akan datang. Dia memberitabu umat Kristen babwa akan datang nabi lain, ketika Nabi Mubammad Shallallabu'alaibi wa Sallam datang, dia akan menuntunmu ke dalam kebenaran.

Setelah Dr. Zakir Naik menanyakan pada wanita Nashrani tentang keyakinan ajaran yang dibawa oleh Nabi Muhammad Shalallahu' alaibi wa Sallam apakah dia punya jawaban yang lebih ilmiah dan percaya dengan agama kedamaian ini?. Wanita Nashrani tersebut terdiam berpikir sejenak dan dan menyebutkan bahwa " iya dia percaya. Dan pada akhirnya wanita Nashrani tersebut meyakini dan beriman kepada Allah Subbanabu wa Ta'ala dan Nabi Muhammad Shalallabu'alaibi wa Sallam. Sehingga akhirnya dia mengakui kebenaran ajaran Islam yang disampaikan oleh Dr. Zakir Naik.

Disinilah letak kekuatan retorika Dr. Zakir Naik yang mampu menghilangkan keraguan pada seseorang bahkan seorang non-Muslim sekalipun, setelah mendengar jawaban dari Dr. Zakir Naik.

Dalam Dr. Zakir Naik menyampaikan jawabannya dengan jelas dan tegas serta adanya kata penekanan dan intonasi yang membuat penanya menjadi fokus terhadap jawaban yang disampaikan oleh Dr. Zakir Naik. Dalam dialog ini Dr. Zakir Naik mengajak kaum Nashrani terutama kepada penanya untuk tidak meragukan agama Islam lagi, sebagai agama yang benar sehingga bisa beribadah kepada Allah semata dengan meniti jalan yang lurus dan tidak meragukan kenabian nabi Muhammad Shalallahu 'alaibi wassalam karna beliau adalah nabi 
terakhir yang datang menyempurnakan ajaran-ajaran sebelumnya. Dr. Zakir Naik juga menjelaskan bahwa Yesus Kristus memberitahukan kepada para pengikutnya , masih banyak yang harus kukatakan padamu tapi kamu belum dapat menanggungnya sekarang, tapi ketika Dia ( roh kebenaran) itu datang, " ini membicarakan nabi Muhammad Shalallabu 'alaibi wassallam" Dia akan memimpin kamu kedalam kebenaran. Dan kita tahu bahwa nabi Muhammad Shalallabu 'alaibi wassallam mendapatkan wahyu dari Allah Subhanabu wa Ta'ala, apapun yang diwahyukan kepadanya, dia mengatakannya secara harfiah dan mengumumkannya kepada dunia. Jadi didalam Bibel, ada banyak nubuat tentang kedatangan nabi penutup dan terakhir yang akan menuntun pada jalan kebenaran. Dan dia adalah nabi Muhammad Shallallabu'alaibi wa Sallam yang mendapat wahyu, dia tidak berkata dari diri sendiri.

Kemudian Dr. Zakir Naik menyampaikan dengan suara lantang dan tegas dengan menyebutkan ayat-ayat Bible, untuk meyakinkan penanya tentang nabi yang akan datang setelah nabi Isya yang akan menuntun kepada kebenaran, yaitu nabi Muhammad Shalallahu 'alaibi wassallam sebagaimana yang disampaikan oleh Yesus ( Nabi Isya) . Dr. Zakir Naik dengan cirinya yang khas yakni dengan sepotong kopiah putih yang selalu bertengger di kepalanya dan sepatu pantofel hitam di sepasang kakinya, menyampaikan dakwah dengan bijak dan berwibawa dihadapan ribuan jama'ah. Dari ceramah itu Dr. Zakir Naik menjelaskan bahwa disebutkan dalam Bibel, di Perjanjian Baru, di gospel Yohanes 16:12-14, Yesus Kristus membicarakan tentang nabi yang akan datang, yang akan menuntun pada jalan kebenaran, dan nabi inilah yang akan memuliakan nabi Yesus. Tapi ketika Dia (roh kebenaran) itu datang, dia akan memimpinmu ke dalam seluruh kebenaran. "Dia! Disitu Yesus tidak berkata "aku", melainkan "dia." Ini artinya orang lain, dan yang dibicarakan oleh Yesus Kristus adalah orang yang akan mendapat wahyu dari Tuhan, dan dia adalah nabi Muhammad Shallallabu'alaibi wa Sallam.

Kemudian pada dialog selanjutnya, Dr. Zakir Naik menyampaikan dengan intonasi yang tinggi rendah. Dalam dialog tersebut Dr. Zakir Naik menjelaskan tentang sejarah Nabi Muhammad Shallallabu'alaibi wa Sallam dan kemuliaan dari agama Islam serta kemuliaan dari Al-Qur'an. "Dan kita tahu dari sejarah bahwa Nabi Muhammad Shallallabu'alaibi wa Sallam mendapat wahyu dari Tuhan. Dan apapun yang diwahyukan padanya, dia mengulanginya secara harfiah. Dan Islam adalah satu-satunya agama selain Kristen yang mewajibkan pengikutnya untuk mengimani Yesus Kristus. Nubuat ini mengatakan "Dia akan memuliakan aku." Jadi dalam Al-Qur'an ini, Yesus Kristus disebutkan namanya 25 kali. Dia dimuliakan! Jadi Yesus Kristus membicarakan tentang Nabi Muhammad Shallallahu'alaibi wa Sallam dan Al-Qur'an. Dapat disimpulkan bahwa Dr. Zakir Naik mengajak kaum Nashrani untuk mempercayai adanya Nabi Muhammad Sballallabu'alaibi wa Sallam yang menuntun pada jalan kebenaran, 
yakni dengan mengamalkan isi Al-Qur'an, karena Al-Qur'an adalah wahyu dari Tuhan dan bukan buatan dari tangan manusia.

Berdasarkan hasil analisis penelitian dan pembahasan yang panjang lebar penulis tuliskan di bab IV tentang retorika dakwah Dr. Zakir Naik dalam meyakinkan kebenaran ajaran Islam kepada kaum Nasrani dengan studi kasus dialog pada video "Wanita Nasrani Akhirnya Mengakui Kebenaran Islam" di chanel yautube Lampu Islam, dapat disimpulkan bahwa pola/model retorika yang digunakan oleh Dr. Zakir Naik adalah pola/model teori retorika logos, yakni isi pesan komunikasi mencakup imbauan berdasarkan argumen yang logis. Yang mana disini Dr. Zakir Naik dapat meyakinkan pendengar dengan mengajukan bukti atau dalil-dalil yang dapat meyakinkan kebenaran ajaran Islam.

Agar efektif dan efesien dalam berdakwah hendaknya kita sebagai muslim-muslimat lainnya pun dapat mengikuti jejak Dr. Zakir Naik, tidak berdiam diri melihat persoalan-persoalan yang sedang terjadi di tengah masyarakat. Yang mana beliau adalah Dokter yang banyak mengIslamkan ratusan ribu orang dan Dokter yang paling berpengaruh di dunia yang mengIslakan jutaan orang. Yang mana beliau menggunakan retorika/seni berbicara guna memenuhi seruan Allah Subbanabu wa Ta'ala.

Dan seharusnya para da'i juga menambah wawasan keilmuannya, Kemudian penulis juga berharap kepada para da'i dan da'iyah dalam menyampaikan dakwahnya juga memiliki kemampuan public speaking yang baik, karena hal itu sangat penting bagi seorang da'i, bagaimana mungkin seorang da'i bisa menyampaikan dakwahnya dengan baik seperti di tempat umum dan di khalayak ramai kepada mad'unya kalau tidak memiliki public speaking yang baik.

\section{KESIMPULAN}

Dalam bab ini penulis akan menyimpulkan hasil penelitian yang telah penulis lakukan berdasarkan rumusan penelitian yang penulis telah tetapkan yakni "Bagaimana Retorika Dakwah Dr. Zakir Naik dalam Meyakinkan Kebenaran Ajaran Islam?”.

Berdasarkan data-data yang bisa penulis dapatkan selama penelitian berlangsung kemudian penulis analisa berdasarkan teori Aristoteles, maka penulis dapat menyimpulkan sebagai berikut:

Secara Ethos (sikap/kredibilitas komunikator), beliau menampakkan sikap bijak dalam menjawab semua pertanyaan dari komunikan. 2. Phatos (respon kumunikan). 3. Logos (isi pesan yang di sampaikan secara logis), isi pesan komunikasi yang banyak disampaikan oleh Dr. Zakir Naik ialah isi pesan yang disampaikan secara logis dan ilmiah, sehingga sangat mudah untuk mendapatkan respon yang positif dari setiap komunikan. Sebagaimana dibuktikan pada sebuah video yang di unggah pada Youtube.co.Lampu Islam pada tanggal 3 April 2017 
di UMY (Universitas Muhammadiyah Yogyakarta) dengan dialog bertema wanita Kristen akhirnya mengakui kebenara Islam. Terbukti bahwa Dr. Zakir Naik beretorika didalam dakwahnya menggunakan teori retorika Aristoteles yaitu Ethos, Pathos, dan Logos. Dapat kita lihat Dr. Zakir Naik sanggup menunjukkan kepada khalayak bahwa dia memiliki pengetahuan yang luas dengan memberikan sebuah contoh dan analogi yang mudah dipahami, sehingga memiliki kepribadian yang terpercaya, dan status yang terhormat dihadapan khalayak. Selain itu Dr. Zakir Naik mampu menyentuh hati khalayak, emosi, harapan, kebencian dan kasih sayang peserta diskusi dengan argumen yang Dr. Zakir Naik sampaikan bahwa agama Islam adalah agama kedamaian. Kemudian Dr. Zakir Naik pun meyakinkan kahalayak dengan mengajukan bukti atau yang kelihatan sebagai bukti.

\section{DAFTAR PUSTAKA}

Abdul Karim bin Az-Zaid Zaid, Fikih Sirah, Mendulung Hikmah dari Sejarah Kehidupan Rasulullah Shallallahu'alaihi wa Sallam, terj. Muhammad Rum, dkk, Jakarta: Darus Sunnah Press, 2009.

Abdullah bin Muhammad bin 'Abdurrahman bin Ishaq Alu Syaikh, Lubabuut Tafsir

Ahmad Jaiz Hartono, Jejak Tokoh Islam dalam Kristenisasi, Jakarta: Darul Falah, 2005.

Albi K., dkk, Dr. Zakir Naik: Dokter yang MengIslamkan Ratusan Ribu Orang, Yogyakarta: Mutiara Media, 2016.

Alkitab, Jakarta: Lembaga Alkitab Indonesia, 2001.

Al-Qardhawi Yusuf, Retorika Islam (Bagaimana Seharusnya Menampilkan Wajah Islam), Jakarta Timur: PUSTAKA AL-KAUTSAR, 2007.

Al-Qathani Said, Menjadi Da'i Yang Sukses, Jakarta: Qisthi Press, 2005.

Amri Syafri (Ed.), Ulil Da'wah Mencari Peluang dan Problematikanya, Jakarta: STID Mohammad Natsir.

Az-Zubaidi Imam, Mukhtasar Shahih Bukhari, terj. Arif Rahman Hakim, Sukoharjo: Insan LS Mokoginta Kamil, 2003.

Bahasa Indonesia untuk Mahasiswa dan Praktik Bisnis, Jakarta: Gramedia Pustaka Utama, 2003.

Berkhof, Sejarah Gereja, Jakarta: PT. BPK Gunung Mulia, 1996.

Bunggin M. Burhan, Sosiologi Komunikasi, Teori, Pradigma, dan Diskursus, Teknologi Komunikasi di Masyarakat. 
Dhiya Arkam' Al-Umuri, Shahih Sirah Nabawiyah, terj. Farid Qurusy, dkk, Jakarta: Pustaka As-Sunnah, 2013.

Emzir, Metode Penelitian Kualitatif Analisis Data, Jakarta Utara: Rajawali Pers,

Eriyanto, Analisis Isi, Pengantar Metodologi untuk Penelitian Komunikasi dan Ilmu-

Hadi Sutrisno, Metodologi Research I, Yogyakarta: YPFP UGM, 1981.

Hamid An-Nashir Muhammad, Menjawab Moderniasi Islam; Membedah Pemikiran

http://internasional.kompas.com, 5 Januari 2019

http://muhammadsubhan. Blogspot.com/2012/05/pengertiam-retorika.html https://m.kitabisa.com 5 Januari 2019

https://www.nesabamedia.com/pengertian-youtube

https://Zakiniku.files.wordpress.co.id. Data Pemurtadan di Indonesia, Dr. Arien dan Dr. Heriansyah

Hulail As-Suhaimi bin Fawaz, Pokok-Pokok Dakwah Manhaj Salaf, Jakarta Timur: GRIYA ILMU, 2011.

Ibnu Katsir, terj. 'Abdul Ghaffar, Jakarta: Pustaka Imam Asy-Syafi'I, 2009.

Ilahi Wahyu, Komunikasi Dakwah 2010,..

ilmu Sosial lainnya, Jakarta: Kencana Prenada Media Group, 2011.

Jamaluddin Al-Afgani Hingga Islam Liberal, terj. Abu Umar Basyir, Jakarta: Darul Haq, 2004.

Jirhanuddin, Perbandingan Agama, Pengantar Studi Memahami AgamaAgama, Yogyakarta: Pustaka Pelajar, 2010.

Jurnal Dakwah Risalah Merintis, Da'wah Melanjutkan, LPPM STID Mohammad Natsir, Bekasi: 2010.

Keraf Gorys, Diksi dan Gaya Bahasa, Jakarta: Gramedia, 2007.

Lih. Tim Fakta, Senjata Menghadapi Pemurtadan Berkedok Islam.

Maarif Zainul, Retorika: Metode Komunikasi Publik, Jakarta: Rajawali Pers, 2015.

MartonoNanang, Metode Penelitian Kualitatif, Analisis isi dan Analisis data sekunder, Jakarta: Rajawali Pres, 2011.

Muhammad, Metode Peneliti Bahasa, Jogjakarta: Ar-Ruzz, 2011. 
Munir Sanihu, Islam Meluruskan Kristen, Surabaya: Victory Press, 2003.

Naik Zakir, dkk, Mereka Bertanya Islam Menjawab, Solo: Aqwam.

Nanang Muhammad, Shafar 1439 H, 21 November 2017.

Natsir Muhammad, Fiqhud Da'wah.

Natsir Muhammad, Islam dan Kristen di Indonesia, Jakarta: Media Dakwah, 1999.

Nugrah Oka I Gusti, Retorika Sebuah Tinjauan Pengantar.

Praptomo Baryadi, I, "Berbagai Pandangan Tentang Kompetensi Berbahasa", dalam Taum, Yoseph Yapi, dkk, Bahasa Merajut Sastra Menurut Budaya, Yogyakarta: Universitas Sanata Dharma, 2004.

Qardawi Yusuf, Islam dan Globalisasi Dunia, terj. Imam Sulaiman, Jakarta: CV. Pustaka Al-Kautsar, 2001,

Rakhmat Jalaludin, Retorika Modern: Pendekatan Praktis, Bandung: PT Remaja Rosda Karya.

Rohman Abdul, YouTube for Profit, TokoMahal.com: Jasakom.com.

Rosyad Shaleh Abd, Manajemen Da'wah Islam, Jakarta: Bulan Bintang, 1986.

Ruslan Rosady, Metode Penelitian, Public Relations dan Komunikasi, Jakarta: Rajawali Pers, 2013.

Soehartono Irawan, Metode Penelitian Sosial, Suatu Teknik Penelitian Bidang Kesejahteraan Sosial dan Soaial Lainnya.

Sofia Adib, Metode Penulisan Karya Ilmiah, Yogyakarta: Karya Media, 2012.

Sugiono, Metode Penelitian Kombinasi (Mixed Methods), Bandung: Alfabeta.

Suhandang Kustadi, Retorika (Strategi, Teknik dan Teknik Pidato), Bandung: NUANSA, 2009.

Syalabi Ahmad, Pengantar Memahami Kristologi, terj. Ahmad, Jakarta: Pustaka Da'i, 2004.

Tajiri Hajir, Etika dan Estetika Dakwah.

Uchjana Effendy Onong, Ilmu, Teori dan Filsafat Komunikasi.

Wahyu, Wibowo, Manajemen Bahasa: Pengorganisasian Karangan Pragmatik dalam WAMY, Gerakan Agama dan Pemikiran (Akar Ideologis dan Pemikirannya) Jakarta: Al-I'tishom Cahaya Umat, 2003.

WAMY, Gerakan Keagamaan dan Pemikiran; Akar Ideology dan Penyiarannya, terj. A. Najiullah, Jakarta: Al-I'tisham, 2003. 
Warson Munawwir Achmad, Kamus Al-Munawwir, Surabaya: Pustaka Progresif, 1997.

www.dictio.id 5 Januari 2019

Zainal Abidin Yusuf, Pengantar Retorika, Bandung: PUSTAKA SETIA, 2013.

Zuriah Nurul, Metodologi Penelitian Sosial dan Pendidikan, Teori-Aplikasi, Jakarta: Aksara, 2009.

Zwemmer Samuel adalah Ketua Asosiasi Agen Yahudi Yerussalem yang pernah memimpin pertemuan misionaris di Kairo Mesir pada abad XX (tahun 1324 H/1906 M). 